\title{
DEVELOPMENT OF AN EYE PROTECTOR FOR PHOTOTHERAPY ON NEWBORNS: A TECHNOLOGY
}

\author{
Lucía Silva ${ }^{1}$ \\ Fernanda Sotrate da Silva ${ }^{1}$ \\ Mariana Turiani ${ }^{1}$ \\ Carmen Maria Casquel Monti Juliani ${ }^{2}$ \\ Wilza Carla Spiri
}

Silva L, Silva FS, Turiani M, Juliani CMCM, Spiri WC. Development of an eye protector for phototherapy on newborns: a technology. Rev Latino-am Enfermagem 2008 janeiro-fevereiro; 16(1):47-51.

Hyperbilirubinemia results from the predisposition of newborns to produce bilirubin and their ability to excrete it. The treatment applied is phototherapy; however, one of its complications is degeneration of the retina by exposure to light, making it essential to provide proper eye protection. The objective of this study is to describe the development of an invention (utility model patented) for eye protection in newborn phototherapy. This invention aims to replace the current widespread practice of using improvised means that are uncomfortable for the baby and disrupt the mother/child relationship. A study was made of the radiances emitted by light sources used in phototherapy. The invention consists of an eye protector model for use during the newborn's phototherapy, allowing greater closeness between mother and baby. The device is easy to use, economical, removable and appropriate for newborns, causing no discomfort, and its effectiveness has been proved through radiance tests.

DESCRIPTORS: phototerapy; technology; newborn; nursing

\section{DESARROLLO DE UN PROTECTOR OCULAR PARA FOTOTERAPIA EN RECIÉN NACIDOS: UNA TECNOLOGÍA}

La Hiperbilirrubinemia resulta de la predisposición que tienen los recién nacidos para producir bilirrubina y de su capacidad para excretarla. El tratamiento aplicado es la fototerapia; una de las complicaciones es la degeneración de la retina por exposición a la luz, por esta razón es esencial efectuar una protección ocular adecuada. El objetivo de este estudio es describir el desarrollo de una invención (modelo de utilidad patentado) para la protección de recién nacidos durante la fototerapia. La invención tiene como objetivo sustituir la práctica común, improvisada e incomoda para el bebé y que interfiere en la relación madre bebé. El estudio fue realizado evaluando la radiación emitida por la luz de la fototerapia. La invención consiste en un modelo de protector ocular usado durante la fototerapia del recién nacido, que permite la aproximación entre la madre y el bebé. Es de fácil uso, económico, removible y apropiado para el recién nacido, ya que no causa incomodidad y se mostró efectivo en las pruebas de radiación.

DESCRIPTORES: fototerapia; tecnología; recién nacido; enfermería

\section{DESENVOLVIMENTO DE UM PROTETOR OCULAR PARA FOTOTERAPIA EM RECÉM- NASCIDOS: UMA TECNOLOGIA}

Hiperbilirrubinemia resulta da predisposição de recém-nascidos em produzir bilirrubina e sua capacidade para excretá-la. O tratamento aplicado é a fototerapia, entretanto, uma das complicações é a degeneração da retina pela exposição à luz, sendo essencial providenciar proteção ocular adequada. O objetivo deste estudo é descrever o desenvolvimento de um invento (modelo de utilidade patenteado) para a proteção de recémnascidos em fototerapia. O invento visa substituir a prática corrente improvisada e desconfortável para o bebê, que interfere na relação mãe-bebê. O estudo foi feito avaliando a radiância emitida pela luz da fototerapia. o invento consiste em um modelo de protetor ocular usado durante a fototerapia do recém-nascido, permitindo aproximação mãe-bebê, além de ser de fácil uso, econômico, removível e apropriado ao recém-nascido, pois não causa desconforto e mostrou efetivo nos testes de radiância.

DESCRITORES: fototerapia; tecnologia; recém-nascido; enfermagem

${ }^{1}$ RN, e-mail: lucia_funes@yahoo.com.br; ${ }^{2}$ RN, Assistant Professor at Botucato Medical School, São Paulo State University "Júlio de Mesquita Filho", Brazil, e-mail: cjuliani@fmb.unesp.br; wilza@fmb.unesp.br 


\section{INTRODUCTION}

Neonatal jaundice has been reported by caretakers for many centuries. However, this phenomenon was first studied and scientifically described by Jean Baptiste Thimotee Baumes in the $18^{\text {th }}$ century, thus beginning a series of other studies about this relevant theme ${ }^{(1)}$.

Between 50 and $75 \%$ of newborns have visible jaundice in their first days of life. However, all babies in this phase have higher plasmatic bilirubin than normal adults, a fact that has already been observed in the blood of the umbilical ${ }^{(2)}$.

The bilirubin increases for a few days, reaching a peak, after which it decreases until the clinical jaundice disappears by the end of the first week, in full-term newborns and a little later in premature babies $^{(2)}$

Jaundice is the most commonly observed clinical sign in newborns in nurseries or in maternity wards where babies remain with their mothers. The newborn taken out of the intrauterine environment needs to adjust to extrauterine life and begins to depend on substrates to maintain the pace if its growth and to supply the energy requirements of its tissue mass. This caloric need depends basically on the liver's activity $^{(3)}$.

Hyperbilirubinemia results from the predisposition of newborns to produce bilirubin and their ability to excrete $i t^{(4)}$.

The hyperbilirubinemia is characterized by a higher serumal concentration of bilirubin than $1.5 \mathrm{mg}$ $\%$. Treatments are applied according to the cause of this increase in bilirubin, and one of the most commonly used means of treating jaundice in newborns is phototherapy ${ }^{(3)}$.

Phototherapy consists of placing the newborn under a source of fluorescent light. Since its discovery, several models have been proposed for the action mechanism of the light beaming onto the skin. It is an accepted fact that the absorbed light causes degradation of the bilirubin impregnated in the skin, transforming it into hydrosoluble by-products that are eliminated from the organism without the need for previous hepatic conjugation ${ }^{(2)}$.

The effectiveness of phototherapeutic treatment depends on the intensity of the light emitted by the equipment, the proximity of the emission spectrum to that of the bilirubin absorption, the postnatal age of the newborn, the gestational age, the weight at birth, the cause of the jaundice and the amount of bilirubin at the beginning of the treatment.

A study revealed that, of the types of lamps utilized in phototherapy, blue lamps provide more effective treatment than halogen lamps ${ }^{(5)}$. However, one of the complications of the method is that is causes degeneration of the retina through exposure to light. Therefore, it is crucial to protect the eyes properly. Some authors say this protection can be provided by bandages, blindfolds or strips of gauze ${ }^{(2)}$.

Study suggest the lack of consensus among healthcare professionals related to the use of phototherapy ${ }^{(6)}$

The technological work organization at the neonatal ICU still shows in its daily life the images of a routine and technical work, marked by the preterm weak body appropriation, which characterizes the biologist and cure model of care ${ }^{(7)}$.

Considering the importance of this protection, the objective of this report is to describe the development of an eye protector device for use on newborns undergoing phototherapy.

\section{METHODOLOGY}

This is a descriptive study. As the radiance tests was carried in the eye protector device whitout exposition of newborn, it wasn't necessary approval in Ethical Committee.

The experiment was carried out at the Joint Ward of the Nursery and Neonatal ICU of a universitary hospital in state of São Paulo, Brazil, in the second semester of 2002, the period when the discipline Administration Applied to Nursing was taught, during which the development of a product was proposed.

The first stage consisted of observing that the eye protection of neonatal patients subjected to phototherapy to treat neonatal jaundice was commonly done, even in hospitals and maternity wards, by improvised means, using bandages or strips of gauze fixed with adhesive tape, and even roughly cutout X-ray films adapted to place over the baby's eyes.

This practice represents innumerable inconveniences and discomfort for the baby and impairs the optimal development of the mother-infant bond in the first days of life, which can, in theory, lead to longer-lasting physical and psychological 
discomfort and repercussions. Indeed, the use of appropriate means of eye protection seems inexistent or unknown, for the literature contains nothing on the subject.

In this practice, in maternities and hospitals, have been identified as episodes of allergy and superficial skin irritations caused by the tape's adhesive substance or small lesions resulting from the cut edges of the $x$-ray films in contact with the infant's skin.

In other instances, keeping the baby's eyes covered with a blindfold even during breastfeeding has been found to impair the mother-infant bond, and mothers feel uneasy upon perceiving their baby's discomfort when the blindfold taped directly onto its skin is removed.

This technique, therefore, has the following disadvantages:

- For the infant: allergies to the glue of the adhesive tape and inefficient protection, since the gauze strip often loosens and peels off from the baby's skin.

- For the mother: impairment of the mother-baby bond, since the mother does not remove the eye protector during breastfeeding because of its impracticality.

- In addition, we found mothers felt extremely anxious when the tape was removed, since it is aggressive to the baby's skin.

- For the institution: higher expenses, because the eye protectors are discardable and cannot be reused.

Having observed these facts, the following step was to make a bibliographic review in the following databases: MEDLINE, LILACS and SCIELO, in search of an eye protection model. However, this survey brought to light only studies about the effects of phototherapy, with no mention of any eye protector model.

\section{RESULTS AND DISCUSSION}

The invention consists of an eye protector for use during phototherapy treatments on newborns, which eliminates all the inconveniences of improved protectors. We believe the device is feasible because it is economical, appropriate, and easy to produce and use.

Although it can be reused, its production on an industrial scale using disposable materials, such as compressed pulp fibers, will allow for a substantial cost reduction of the product.
Based on the above, we present the eye protector for phototherapeutic applications on newborns. The product offers the following advantages: - Disappearance or reduction of baby skin allergies caused by adhesive tape glue.

- More effective protection, since the Velcro fastening tape will not easily come undone.

- Enhancement of the mother-baby bond, since the mother can easily remove the protector to breastfeed the infant.

- Lower expenses for the institution, since the device can be washed at the hospital, allowing for its reuse by several babies.

The mother's presence during phototherapy is a beneficial factor that minimizes the effects on the infant's behavior, allowing for the establishment of the mother-infant bond during the process and encouraging continuing breastfeeding and all the mother-child interactions ${ }^{(8)}$.

Stages of Device Tests

To begin with, a study was made of the radiances emitted by light sources used in phototherapy, measuring the protection provided by the usual improvised means. Studies were also conducted to measure the cranial circumference of newborns.

The radiance tests was carried out after consulting the literature ${ }^{(9)}$, which indicates the following points as ideal in conventional phototherapy: - 3 or 4 blue lights and 4 white lights placed at a distance of $30 \mathrm{~cm}$ from the baby's xiphisternum, emitting a radiance of approximately 7 to $11 \mathrm{~cm} \mu \mathrm{w} / \mathrm{cm}^{2} \mathrm{~nm}$; - 8 white lights, located at the same distance from the baby, emitting a radiance of 4 to $5 \mathrm{~cm} \mu \mathrm{w} / \mathrm{cm}^{2} \mathrm{~nm}$.

In phototherapy using halogen light, from a distance of 30 to $40 \mathrm{~cm}$, one should obtain a radiance of 11 to $14 \mathrm{~cm} \mu \mathrm{w} / \mathrm{cm}^{2} \mathrm{~nm}$. This type of phototherapy is more recommended for premature infants.

The test was carried out using a convention

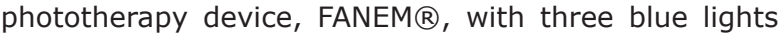
and four white lights, on a infant manikin. The device emitted a radiance of $7.9 \mathrm{~cm} \mu \mathrm{w} / \mathrm{cm}^{2} \mathrm{~nm}$ at a distance of $30 \mathrm{~cm}$ from the light source to the infant maniki's xiphoid process.

The radiance emitted at a distance of $26 \mathrm{~cm}$, which corresponds to the height of the device to the infant's eyes, was $6.8 \mathrm{~cm} \mu \mathrm{w} / \mathrm{cm}^{2} \mathrm{~nm}$.

The parameter adopted was the radiance emitted to the baby using the improvised protector. 
The value found for the height of the eyes was 1.8 $\mathrm{cm} \mu \mathrm{w} / \mathrm{cm}^{2} \mathrm{~nm}$ with the $\mathrm{x}$-ray plate and $1.9 \mathrm{~cm} \mu \mathrm{w} /$ $\mathrm{cm}^{2} \mathrm{~nm}$ without the plate. Using the invention, the radiation was found to be $1.7 \mathrm{~cm} \mu \mathrm{w} / \mathrm{cm}^{2} \mathrm{~nm}$ with the $\mathrm{x}$-ray plate and $1.8 \mathrm{~cm} \mu \mathrm{w} / \mathrm{cm}^{2} \mathrm{~nm}$ without the plate.

Therefore, as can be seen, the protection provided by the protector with the $x$-ray plate is minimal compared with that provided without the $x$ ray plate, which led us to decide to use only the protector made of fabric.

The test was also conducted with Bilispot (FANEM $®$ ) phototherapy on a infant manikin. Using the protector adapted with gauze, a radiance of $1.9 \mathrm{~cm} \mu \mathrm{w} /$ $\mathrm{cm}^{2} \mathrm{~nm}$ was emitted, with and without the $\mathrm{x}$-ray plate.

The radiance emitted with the invention was $1.8 \mathrm{~cm} \mu \mathrm{w} / \mathrm{cm}^{2} \mathrm{~nm}$, both with and without the $\mathrm{x}$-ray plate.

Defining the invention

The size and shape of the newly invented protector were defined based on measurements of the cephalic perimeter of babies at the joint ward of the nursery and neonatal ICU of a universitary hospital of the state of São Paulo, Brazil.

The following preferred standard measurements were defined for the protector and its component parts: - $3 \mathrm{~cm}$ width $\times 9 \mathrm{~cm}$ length for the eye protector or blindfold;

- $1.25 \mathrm{~cm}$ width $\times 30 \mathrm{~cm}$ length for the tape to pass through the loop

- $1 \mathrm{~cm}$ width for the fixing tape.

The eye protector (blindfold) can be made of any opaque, sterile or sterilized material, such as cotton fabric, flexible plastic film, or pressed pulp fiber, or a combination of these materials, shaped anatomically to fit over and cover the infant's eyes, with a cutout in the center for the nose (similar to a pair of eyeglasses).

On one side, the blindfold has a loop or slit through which to pass the $1 \mathrm{~cm}$ wide tape, and this slit is a few millimeters larger than the width of the fixing tape.

The fixing tape is a $30-\mathrm{cm}$ long extension of the body of the blindfold, on which a velcro or similar tape is sewn or fixed on in some way to allow it to be adjusted at regular or irregular intervals or stages so that, upon passing the tape through the loop and folding it over itself, the two sides of the Velcro will fix come together, adjusting the tape securely to the exact size of the baby's head.

This product was produced by the sewing sector of the University Hospital of Botucatu, SP, Brazil.
A sample of the newly invented eye protector device is shown in the attached photographs in the Figure 1

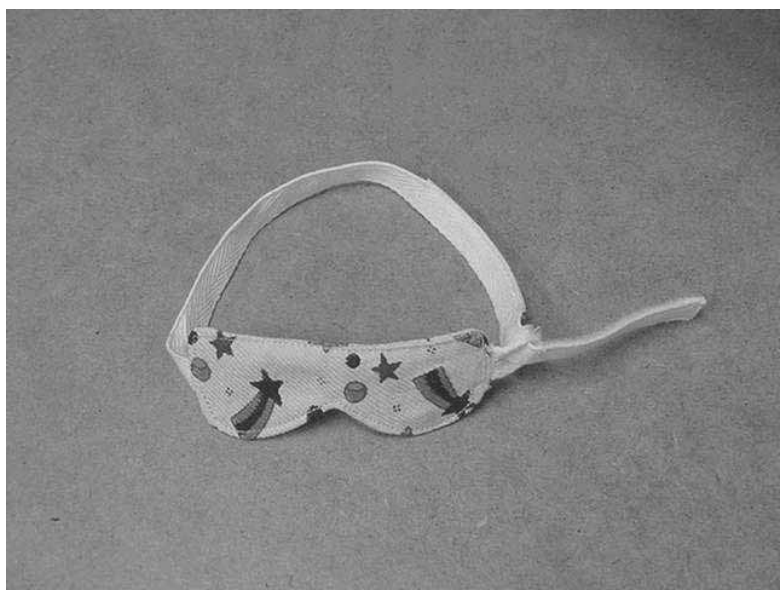

Figure 1 - Eye protector with the tape passing through the loop. Patent: MU 8203353-6.

This sample simply represents one way pf producing the device, for which there are no restrictions in terms of appearance of materials employed. The sample was sewn in cotton fabric with designs appropriate for children, and serves as an example.

\section{FINAL CONSIDERATIONS}

The invention, an eye protector for use during phototherapy, offers several benefits, such as more effective protection during exposure, does not damage the baby's skin, helps enhance the motherinfant bond, is low cost, easy to produce and simple to use.

Mother's speeches reveal their worry about the eyes blindfold used for newborns. They prefer do not remove it to do not hurt the baby $\operatorname{skin}^{(10)}$.

We believe that the presence of the mother with the baby during phototherapy is a factor that contributes to minimize the effects of the treatment on the newborn's behavior, allowing for better interaction during the process as well as encouraging the mother to continue breastfeeding.

We would like to point out that the request for a patent for this invention, as a utility model, has been filed by the Brazilian CNPq - National Council for Scientific and Technological Development, and is being overseen by legal council. The Brazilian National Institute of Intellectual Property (IPNI) registred the patent under number MU 8203353-6. 


\section{REFERENCES}

1. Hansen TW. Pioneers in the science study of neonatal jaundice and kernicterus. Pediatrics 2000 August; $106(2): 15$.

2. Ramos JLA, Vaz FAC, Araújo MCK. Icterícia do recémnascido. In: Marcondes E. Pediatria básica. São Paulo (SP): Sarvier; 2002. p.466-85.

3. Alves Filho N. Hiperbilirrubinemia do recém-nascido: conduta prática. In: Alves Filho N, Correa MD. Manual de Perinatologia. Rio de Janeiro (RJ): MEDSI; 1990. p. 695732.

4. Denery PA, Seidman DS, Stevenson DK. Drug therapy: neonatal hyperbilirubinemia. N Engl J Med 2001 February; 344(8): 581-90.

5. Pachi PR, Magalhães M, Silva LVRF. Comparative study between the efficacy of phototerapy with halogen and with special blue light in the treatment of hyperbilirubinemia in full term neonates. Pediatr Res 1998 April; 43(4, Suppl 2):187. 6. Vieira AA, Lima CLMA, Carvalho M, Moreira MEL. Phototherapy in the newborn infant: evaluation of clinical practice. Rev Bras Saude Mater Infant 2004 OctoberDecember; 4(4):359-66.

7. Gaiva MAM, Scochi CGS. Working process in health and nursing at a neonatal ICU. Rev Latino-am Enfermagem 2004 maio-junho; 12(3):469-76.

8. Abrol P, Sankarasubramanian R. Effect of phototherapy on behavior of jaundiced neonates. Indian J Pediatr 1998 JulyAugust; 65(4):603-7.

9. Daher SR, Rodrigues LR. Icterícia neonatal. In: Departamento de Pediatria da FMB - UNESP. Condutas em Pediatria. Rio de Janeiro (RJ): Epub; 1999. p. 161-71.

10. Campos ACS, Cardoso MVLML. O recém-nascido sob fototerapia: a percepção da mãe. Re. Latino-am Enfermagem 2004 julho-agosto; 12(4):.606-13. 